\title{
Supermarket and Grocery Store-Based Interventions to Promote Healthful Food Choices and Eating Practices: A Systematic Review
}

Anne L. Escaron, PhD, MPH; Amy M. Meinen, MPH, RD; Susan A. Nitzke, PhD, RD; Ana P. Martinez-Donate, $\mathrm{PhD}$

Suggested citation for this article: Escaron AL, Meinen AM, Nitzke SA, Martinez-Donate AP. Supermarket and Grocery Store-Based Interventions to Promote Healthful Food Choices and Eating Practices: A Systematic Review. Prev Chronic Dis 2013;10:120156. DOI: http://dx.doi.org/10.5888/pcd10.120156国.

PEER REVIEWED

\section{Abstract}

\section{Introduction}

Increasingly high rates of obesity have heightened interest among researchers and practitioners in identifying evidence -based interventions to increase access to healthful foods and beverages. Because most food purchasing decisions are made in food stores, such settings are optimal for interventions aimed at influencing these decisions. The objective of this review was to synthesize the evidence on supermarket and grocery store interventions to promote healthful food choices.

\section{Methods}

We searched PubMed through July 2012 to identify original research articles evaluating supermarket and grocery store interventions that promoted healthful food choices. We categorized each intervention by type of intervention strategy and extracted and summarized data on each intervention. We developed a scoring system for evaluating each intervention and assigned points for study design, effectiveness, reach, and availability of evidence. We averaged points for each intervention category and compared the strength of the evidence for each category.

\section{Results}

We identified 58 articles and characterized 33 interventions. We found 7 strategies used alone or in combination. The most frequently used strategy was the combination of point-of-purchase and promotion and advertising (15 interventions); evidence for this category was scored as sufficient. On average, of 3 points possible, the intervention categories scored 2.6 for study design, 1.1 for effectiveness, 0.3 for reach, and 2 for availability of evidence. Three categories showed sufficient evidence; 4 showed insufficient evidence; none showed strong evidence.

\section{Conclusion}

More rigorous testing of interventions aimed at improving food and beverage choices in food stores, including their effect on diet and health outcomes, is needed.

\section{Introduction}

Obesity, overweight, and health outcomes associated with poor nutrition (1) represent a significant economic and social burden in the United States. Annual medical costs attributed directly to obesity and overweight were estimated at $\$ 147$ billion in 2008 (2). Public health researchers and practitioners are working to identify evidence-based interventions to promote more healthful eating practices. The Dietary Guidelines for Americans 2010 recommend stronger environmental strategies for improving the population's eating practices, including interventions to influence food purchasing behaviors in stores (3).

Supermarkets play an important role in food purchasing (4); consumers averaged 2.2 trips per week to the supermarket in 2010 (5). They also represent an optimal setting for interventions aimed at improving food purchase 
decisions. Supermarket and grocery store interventions are consistent with a social ecological approach $(6,7)$, and the availability of healthful foods in food stores affects consumers' ability to make healthful dietary choices $(4,6)$. Lowincome populations purchase a high proportion of their food as prepared foods and from small stores, which has implications for intervention development (8).

Several reviews on food store interventions have found strong evidence for feasibility but only modest evidence for effectiveness in changing eating behaviors (4,9-11). A review on interventions in small food stores (12) indicated that 9 of 10 studies observed an increase in the number of purchases of targeted foods. The relationship between large food stores and dietary intake has received attention (13). The objective of this review was to review, summarize, and assess the level of evidence on supermarket and grocery store interventions to promote healthful food choices.

\section{Methods}

\section{Data sources}

We searched all years of PubMed for original research articles and qualitative and quantitative reviews (meta-analyses) describing supermarket and grocery interventions that promoted healthful food choices. We used a combination of keywords ("grocery store," "grocery stores," "supermarket," and "supermarkets") and 1 MeSH term ("health promotion"). An initial search yielded 140 citations dated from the late 1940s through July 2012.

\section{Study selection}

When we included only English-language articles, 134 remained. The first author (A.L.E.) read each title and abstract; if the article was relevant, she read the full text. She narrowed the search to include only original research articles that described community- (those initiated by public health practitioners) and store-based interventions (in which store involvement was described). She excluded clinical screening interventions and controlled marketing field experiments, articles that did not report the targeted outcomes, and other articles that were not within the scope of the review. She reviewed citations in the selected articles and included those articles if they met criteria. As a result, 58 articles published from 1978 through 2012 were included for further analysis; the 58 articles described 33 interventions.

\section{Data extraction}

The first author (A.L.E.) categorized each article according to the intervention described and the strategy or combination of strategies used in the intervention (Figure). The 4 strategies were point-of-purchase (POP) information, pricing, increased availability of healthful foods, and promotion and advertising. These strategies are consistent with those used previously (4). 


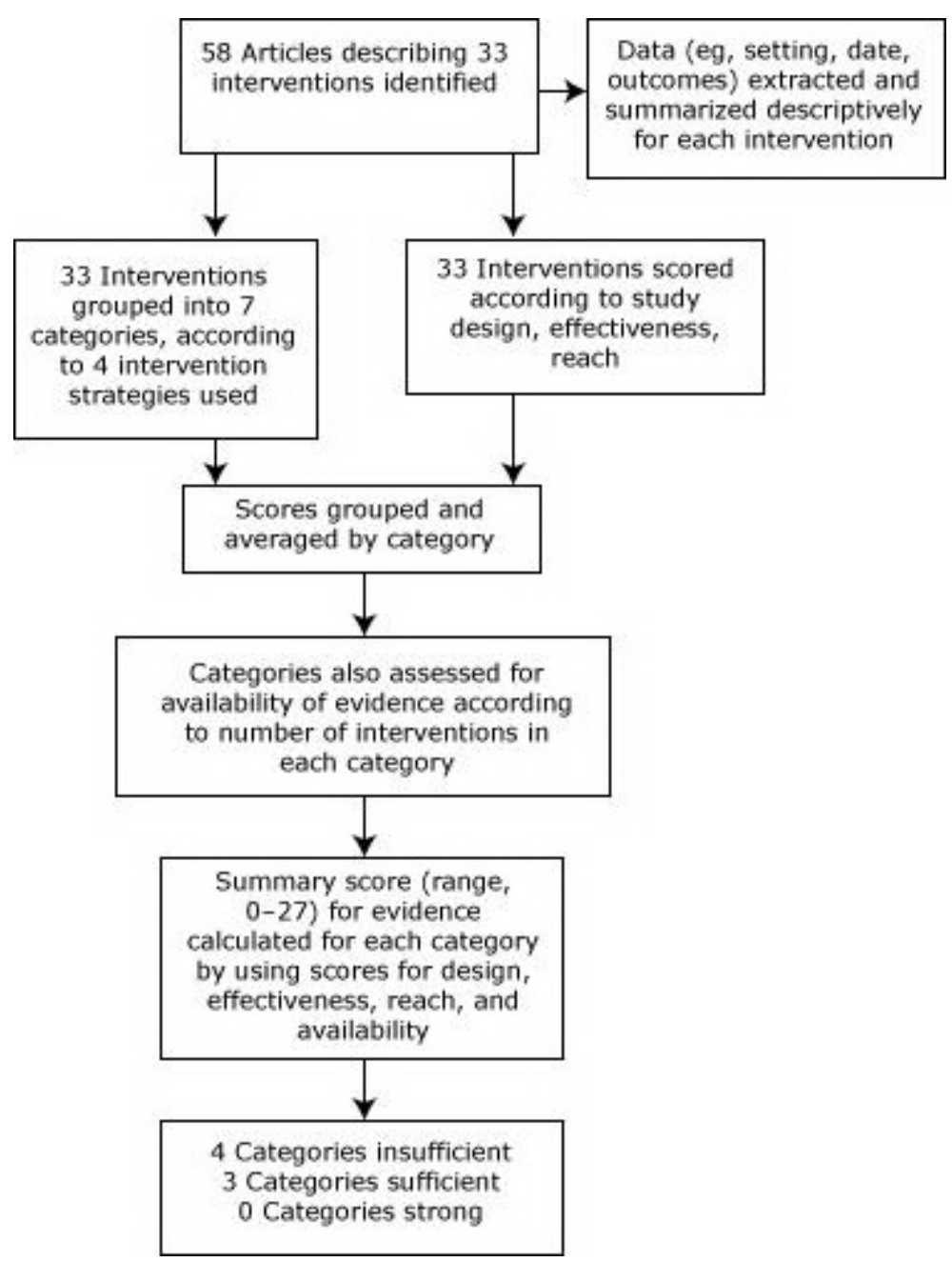

Figure. Data extraction and analysis for systematic review on supermarket and grocery store-based interventions to promote healthful food choices and eating practices, United States, 2012. [A text description of this figure is also available.]

POP interventions typically entail the use of food demonstrations, taste testing, signs, labels, and other printed materials highlighting healthful food choices or describing recipes with the goal of influencing purchasing decisions toward more healthful options (4). Interventions based on pricing use reduced prices and coupons to promote healthful options $(4,10)$. Interventions based on increased availability work to provide more healthful food choices (4). Promotion and advertising strategies use games, newspaper inserts, multimedia advertising, supermarket tours, and other activities to promote the purchase of more healthful foods (4).

The first author extracted the following data for each intervention: the theory on which the intervention was based (eg, social cognitive), intervention setting, location, year in which an article was published; description of intervention activities and duration; study design (eg, concurrent comparison group, prospective measurement of outcomes); and main outcomes measured.

The main outcomes were awareness and use, sales data, customers' knowledge and beliefs (14), preferences, intentions, and process measures (15-17). Awareness and use refers to the percentage of surveyed customers who noticed the intervention materials and believed their purchasing decision was influenced by them. Sales data refers to objective measurements of customers' purchasing decisions for a category of food or item. Preferences serve as a predictor of target food consumption $(18,19)$. Intentions refer to behavioral intentions to prepare, select, and consume more healthful foods (19). Process measures included reach, dose, and fidelity; reach is the number of target audience members exposed to any component of the intervention (20), dose is the number of times each target audience member was exposed to any intervention component (21), and fidelity is the extent to which an intervention was implemented as planned (15). When interventions reported on fruit and vegetable intake, fat intake, or dietary intake, we also extracted these data. 
We created an assessment schema on the basis of accepted terminology in the Guide to Community Preventive Services (Community Guide) (22) and other definitions (20) and categories (15). For each of 3 characteristics - study design, effectiveness, and reach - the first author assigned points to each intervention according to her assessment. Study design was scored as 1, 2, or 3 points, according to the suitability of study design to determine effectiveness $(15,22)$. Greatest suitability (3 points) was defined as a study that had a concurrent comparison group and prospective measurement of outcomes. Moderate suitability (2 points) was defined as retrospective designs or studies that had multiple pre- or postmeasurements but no concurrent comparison group. Least suitability (1 point) was defined as before-after studies that had no comparison group or studies in which outcomes were measured in a single group at the same point in time. We did not assign zero points for study design.

Effectiveness was scored as o to 3 points, according to effectiveness of the intervention's main outcome measures (eg, awareness and use). Studies reporting a $70 \%$ to $100 \%$ increase pre- to posttest or between comparison and intervention groups in outcomes (eg, awareness and use) of the intervention were assigned 3 points. Studies reporting a $26 \%$ to $69 \%$ increase received 2 points. Studies reporting a $1 \%$ to $25 \%$ increase received 1 point. A score of o was assigned if no difference in outcomes was reported between study groups. Most studies reported effectiveness as awareness or use of their intervention (20). If awareness and use were not reported, we assessed the intervention's main outcome measures (eg, knowledge and beliefs, sales data, preferences, intentions, fruit and vegetable intake, fat intake, dietary intake) and used the same scoring. When an intervention had no effect on awareness or use but had a significant effect on sales data or preferences or intentions, we scored the alternative outcomes.

Reach was also scored as o to 3 points. According to the RE-AIM evaluation framework (20), reach is determined by dividing the number of intervention participants by the number of people in the targeted population. For interventions reaching $70 \%$ to $100 \%$ of the population, 3 points were assigned; for $26 \%$ to $69 \%, 2$ points; for $1 \%$ to $25 \%, 1$ point; and for $0 \%$, o points.

For each intervention category (eg, POP), we calculated the average number of points for study design, effectiveness, and reach. We used the sum of these averages as 1 of 2 subscores.

For each intervention category, we assessed the availability of data using the following scoring system. We gave 3 points to categories that included 10 to 30 interventions, 2 points to categories that included 2 to 9 interventions, and 1 point to categories used by only 1 intervention. These points represented the second subscore and functioned as an indicator of the amount of evidence available.

We calculated a summary score (range, $\mathrm{O}-27$ ) for each intervention category by multiplying the 2 subscores. We created 3 classes of evidence on the basis of the summary score: insufficient (o-9 points), sufficient (10-18 points), and strong (19-27 points). These classes were based on Community Guide designations (22). For all strategies combined, the scores for all 5 categories (ie, availability of evidence, study design suitability, effectiveness, reach, and overall summary) scores were summed and then divided by the number of categories.

\section{Results}

The 33 interventions were implemented in the United States $(n=22)$, Canada $(n=4)(23-26)$, and 5 other countries $(\mathrm{n}=7)(27-33)$. In the United States, 4 interventions were in Baltimore, Maryland (34-37); 7 were in the Midwest (38 $-44)$. Most interventions $(n=28)$ were implemented in grocery stores or supermarkets. Only 8 $(24,26,28,33,37,39,45,46)$ targeted $\mathrm{racial} / \mathrm{ethnic}$ minority populations or populations that had low socioeconomic status. Social cognitive theory $(19,47)$ was the most frequently used theory, undergirding 6 studies; the same research group generated most $(28,37,45,46,48)$ of these. The consumer information processing model was the next most frequently used theory; it was used by 3 studies $(34,38,49)$. Three studies $(42,46,50)$ referenced social marketing theory (51). Nine studies used environmental strategies $(23,24,29,34,35,43,52-54)$ and 19 studies used nutrition education $(23,24,29,31-33,35,39-41,43,44,52-58)$ as both rationale and framework. The most frequently reported outcomes were awareness and use (17 studies) and knowledge and beliefs (18 studies), followed by sales data and process measures.

Interventions were organized into the following categories (Table 1): POP $(\mathrm{n}=6)$; POP and pricing $(\mathrm{n}=1)$; POP and promotion and advertising $(\mathrm{n}=15)$; POP, pricing, and promotion and advertising $(\mathrm{n}=4)$; POP, increased availability of healthful foods, and promotion and advertising $(\mathrm{n}=3)$; POP, pricing, increased availability of healthful foods, and promotion and advertising $(n=2)$; and pricing and promotion and advertising $(n=2)$.

The following average scores for all 7 categories were obtained: study design suitability, 2.6 (range, 1.5-3.0), effectiveness, 1.1 (range, $0-1.8$ ), and reach, 0.3 (range, $0-1.0$ ) (Table 2). The overall summary score for all categories combined was 8.0 (range, 3.0-12.2).

Six interventions used randomization; 2 of these used POP (23,59); 1 used POP and pricing (38); 2 used POP and promotion and advertising (29,49); and 1 used pricing and promotion and advertising (33). On average, randomized 
interventions had fewer points for effectiveness (0.7 points [range, $0-1]$ ) than the 27 interventions that did not use randomization (1.4 points [range $0-3])(24-28,30-32,34-37,39-46,50,52-54,56-58)$.

\section{POP and promotion and advertising}

The level of evidence for this category $(24,25,29,34-36,39-41,49,50,53-57,62-74)$ was sufficient. Only 7 interventions reported objective store sales data $(34-36,40,50,53,57)$. Among them, $5(34,36,40,50,53,57)$ showed increased sales of featured items and 1 intervention (35) showed no change. Only 3 interventions $(34,49,50)$ cited a theoretical model as a framework; 1 of these interventions $(49,73,74)$ included a policy component. The intervention "1\% Or Less" (57) reported that $90 \%$ of people randomly selected for a telephone survey postintervention were aware of the campaign. The 5 A Day program's use of audio communications was implemented as planned during the study period (49)

\section{POP, increased availability of healthful foods, and promotion and advertising}

The level of evidence found for this category $(26,28,46,48,76,77)$ was sufficient. In these interventions, staff worked closely with community members to determine which foods contributed most to total fat and overall calories and identified culturally relevant foods to promote. Researchers also worked with food store owners and managers to stock promoted foods and then advertised these products to consumers, thus simultaneously addressing the supply and the demand sides of healthful eating. Marshall Islands Healthy Stores (28) reported high levels of consumer exposure to the mass media components. Two interventions included self-reported purchasing data for evaluation purposes and reported a positive intervention effect. Two of 3 studies reported moderate to high fidelity; Marshall Islands Healthy Stores reported on logistical difficulties with program written materials. All of these interventions drew on social cognitive theory and included assessments of knowledge, beliefs, and intentions. One intervention (46) relied also on the social marketing framework (51). All interventions targeted low-income or racial/ethnic minority populations and were tailored to the communities in which they were implemented with culturally relevant materials and messaging.

\section{POP, pricing, promotion and advertising, and increased availability of healthful foods}

The level of evidence for this category (17,37,45,78-80) was sufficient. Baltimore Healthy Stores (79) was a feasibility trial and not intended to reach a large number of consumers; however, the intervention reached $5 \%$ of the target population. This study collected weekly data on store sales of promoted foods (37); weekly sales of promoted foods increased in intervention stores only when stocking improved. Both programs were implemented with high fidelity. Evaluation of the other intervention included self-reported food purchases of promoted foods (45). The social cognitive theory informed both interventions, and one (45) drew also on the theory of planned behavior, reporting increased caregiver food-related knowledge but not increased intentions to purchase healthful foods.

\section{POP, pricing, and promotion and advertising}

Although this category had insufficient evidence $(27,30,31,42,75)$, it had the highest score for effectiveness. One intervention reported on successful nationwide dissemination of supermarket tours $(31,75)$. Two interventions referenced a theoretical model. One (30) was based on the theory of planned behavior and the other (42) on social marketing principles. Two $(27,31)$ interventions included self-report purchasing habits.

\section{POP}

The level of evidence for this category $(23,32,44,52,58-61)$ was insufficient. Five $(32,44,52,58,59)$ interventions evaluated sales of targeted items; of these, $2(32,59)$ influenced some shoppers to purchase targeted foods. One intervention (59) was based on social cognitive theory, and another (58) relied on the knowledge-attitude-performance model of behavioral change.

\section{Pricing and promotion and advertising}

The level of evidence for this category $(33,43,81)$ was insufficient. One intervention's (43) evaluation relied on customer self-report food purchasing data, and the other (33) reported on participant recruitment.

\section{POP and pricing}

The level of evidence for this category (38) was insufficient. Self-reported shopping and dietary habits (fruit and vegetable intake) were the primary outcomes, but the authors were unable to systematically compare these data between intervention and comparison stores because of inconsistent monitoring. The intervention was based on the consumer information processing model.

\section{Discussion}


The average level of evidence for the interventions summarized in this review nears a sufficient designation but was insufficient overall. Our review generated 4 main findings. First, demand-side interventions (ie, those using POP or promotion and advertising strategies) represented most of the evidence for the study period. Second, evaluation of food store interventions in the early literature emphasized awareness of the interventions, use of the interventions, or both among target populations while excluding other important measures. Store-based strategies evolved to address the supply side, using such strategies as pricing $(27,43)$ and increased availability of healthful foods $(28,46,76,37)$, while continuing to increase demand by using the 2 previous approaches (POP and promotion and advertising). Innovative supply-side interventions were mostly implemented in smaller stores and could be part of a strategy for working in multiple aspects of the food environment. Reporting on process measures such as dose and fidelity is an additional strength of these interventions, allowing for elucidation of the most active components of an intervention. The transition from demand- to supply-side strategies suggests maturation in public health planning and evaluation increasingly based on social and behavioral theoretical models and addresses barriers some communities face when trying to access healthful foods. In communities with limited access to healthful foods, combining culturally sensitive demand- and supply-side strategies is effective in promoting positive food-related behaviors. Third, our review suggests that mass media campaigns accompanying POP interventions $(57,70-72)$ have been effective population-level approaches to influence consumers' decisions on purchasing lower-fat beverages. Finally, the limited use of randomization in food store intervention design reflects the difficulties inherent in applying this design to communitybased health promotion interventions and the greater suitability of quasi-experimental designs.

We found limited evidence on the effect of the interventions on customer purchasing behavior. Eight $(34,36,37,40,50,53,57,59)$ of 13 interventions collecting store sales data demonstrated an increase in targeted product purchases, and 13 interventions presented self-reported data on purchasing behaviors. One of these, a 12-week childfocused intervention (50) yielded a significant increase in the proportion of sales of featured items to total store sales. The intervention displayed fruit, vegetable, and healthful snack samples in a low-to-the-ground kiosk. Similarly successful interventions targeting low-income populations and drawing on social cognitive theory (46) and social marketing (79) were more likely to include components such as taste tests and focus on purchasing of more healthful items, fruit and vegetable acquisition, and food preparation.

Strengths of our study include the up-to-date systematic analysis of 58 articles identified through a comprehensive database and consideration of previous reviews $(4,9-11,82)$. In a departure from an earlier review (4), we assessed each intervention by strategy or combination of strategies used, and we developed new categories to describe the simultaneous use of more than 1 strategy.

Our study had several limitations. In an attempt to be comprehensive and include all evidence available to date, we included 7 studies from the late 1970s and the 1980s; data from older studies may not be relevant to today's food environment. Findings for unsuccessful campaigns are less likely to be published in publications searchable in PubMed. We searched for published studies rather than nonpublished reports or gray literature because published articles tend to have more standardized information on setting, study design, evaluation methods, and results. We searched PubMed only. Highly controlled marketing experiments (83-87) may offer additional insights on effective strategies, but we did not include them because of their less direct translation into community-based interventions. Systematically assessing effectiveness was challenging because of the diversity in community-based interventions; many of the studies were conducted in other settings, such as small stores (37) and schools (48). Only 1 reviewer classified and scored the intervention; the classification and scoring were not verified by a second reviewer. In assessing study design, we did not differentiate between studies that used randomization and studies that did not use a control group. The differences in effectiveness suggest our estimates on levels of evidence may overestimate the actual effectiveness of food store interventions, because some of the results we assessed may have reflected baseline differences between treatment and control groups beyond the interventions implemented. Finally, because the availability of evidence was calculated as 1 of 2 subscores, newer intervention strategies will, by default, given our methods, have less research data available. Yet, some of these may offer promise given the quality of the evidence and their significant results $(42,46,79)$.

This review focused on supermarket and grocery store interventions. Food store interventions represent only 1 level of approach among many levels - from the individual to policy (6). Increasingly, public health agencies such as the Centers for Disease Control and Prevention (88) are encouraging local communities to incorporate policy-level approaches to improve access to healthful foods (89). Task forces (90) and state and local food policy councils $(91,92)$ have been proposed as critical elements of such efforts. These organizations leverage public incentives to help obtain financing through such mechanisms as tax exemptions, Community Development Block Grants, state grants such as the Pennsylvania Fresh Food Financing Initiative (93) (upon which Healthy Food Financing Initiative federal efforts have been based), and loans to supermarkets in underserved communities. They also ensure that funded stores participate in state food assistance programs $(89,92)$. State and local government can, among other activities, expedite approval processes to stimulate supermarket development or encourage pedestrian-friendly development to help patrons avoid transportation barriers $(89,92)$. Neighborhood retail analysis, incentives for energy-efficient equipment and systems, and incentives for locally grown products are other policy approaches. 
Practitioners need access to up-to-date evidence when approaching grocery and supermarket owners or managers to implement interventions. Food stores want practical strategies that will change consumer behavior (94); they also need a return on investment for increasing access to more healthful foods. Some in-store efforts such as 500 Club and Footsteps to Health (www.getactivelacrosse.org/lacrosse/) complement larger environmental change, and policy initiatives (www.healthinpractice.org/ and SOS Shopping Matters), such as nutrition benefit interventions (eg, Supplemental Nutrition Assistance Program Education enacted by Healthy, Hunger-Free Kids Act of 2010) to emphasize obesity prevention as well as nutrition education and are consistent with the socioecological model $(6,7)$, which posits that multilevel interventions addressing the connections between people and their environments maximize the effect of interventions at each level.

Our systematic review of supermarket and grocery store interventions to promote healthful eating suggests that interventions combining demand- as well as supply-side strategies have sufficient evidence to influence customers and management toward more healthful food purchases. The most effective strategies should be combined, and more rigorous evaluation designs should be used. Recent reports of the relationship between the food environment and health outcomes provide impetus for interventions to target food deserts (95-99) and represent an opportunity to add to evidence (12). Consistent with the socioecological model, public health practitioners are encouraged to use multilevel interventions, including policy and environmental change strategies, and to examine health outcomes during evaluation of these interventions.

\section{Acknowledgments}

This work was carried out while Anne Escaron was a primary care research fellow supported by a National Research Service Award (no. T32HP10010) from the Health Resources and Services Administration to the University of Wisconsin Department of Family Medicine. Funding for this project was also provided by the University of Wisconsin School of Medicine and Public Health through The Wisconsin Partnership Program.

\section{Author Information}

Corresponding Author: Anne L. Escaron, PhD, MPH, Department of Population Health Sciences, University of Wisconsin School of Medicine and Public Health, 610 Walnut St, 707 WARF, Madison, WI 53726-2397. Telephone: 310-486-1777. E-mail: aescaron@gmail.com.

Author Affiliations: Amy M. Meinen, Wisconsin Department of Health Services, Madison, Wisconsin; Susan A. Nitzke, Ana P. Martinez-Donate, University of Wisconsin-Madison, Madison, Wisconsin.

\section{References}

1. Kung HC, Hoyert DL, Xu J, Murphy SL. Deaths: final data for 2005. Natl Vital Stat Rep 2008;56(10):1-120. PubMed 国

2. Finkelstein EA, Trogdon JG, Cohen JW, Dietz W. Annual medical spending attributable to obesity: payer-and service-specific estimates. Health Aff (Millwood) 2009;28(5):w822-31. CrossRef 圈 PubMed 圈

3. US Department of Agriculture and US Department of Health and Human Services. Dietary guidelines for Americans, 2010. Washington (DC): US Government Printing Office; 2010.

4. Glanz K, Yaroch AL. Strategies for increasing fruit and vegetable intake in grocery stores and communities: policy, pricing, and environmental change. Prev Med 2004;39(Suppl 2):S75-80. CrossRef 恩 PubMed 圈

5. Supermarket facts. Food Marketing Institute. http://www.fmi.org/facts_figs/?fuseaction=superfact. Accessed May 27, 2011.

6. Story M, Kaphingst KM, Robinson-O’Brien R, Glanz K. Creating healthy food and eating environments: policy and environmental approaches. Annu Rev Public Health 2008;29(1):253-72. CrossRef

7. Stokols D. Translating social ecological theory into guidelines for community health promotion. Am J Health Promot 1996;10(4):282-98. CrossRef 圈 PubMed 圈

8. Gittelsohn J, Sharma S. Physical, consumer, and social aspects of measuring the food environment among diverse low-income populations. Am J Prev Med 2009;36(4Suppl):S161-5. CrossRef 国 PubMed 圈

9. Glanz K, Mullis RM. Environmental interventions to promote healthy eating: a review of models, programs, and evidence. Health Educ Q 1988;15(4):395-415. CrossRef 圈 PubMed 圈

10. Glanz K, Hewitt AM, Rudd J. Consumer behavior and nutrition education: an integrative review. J Nutr Educ 1992;24(5):267-77. CrossRef 圈

11. Mayer JA, Dubbert PM, Elder JP. Promoting nutrition at the point of choice: a review. Health Educ Q 1989;16 (1):31-43. CrossRef 圈 PubMed 国 
12. Gittelsohn J, Rowan M, Gadhoke P. Interventions in small food stores to change the food environment, improve diet, and reduce risk of chronic disease. Prev Chronic Dis 2012;9:E59. PubMed 圈

13. Larson NI, Story MT, Nelson MC. Neighborhood environments: disparities in access to healthy foods in the U.S. Am J Prev Med 2009;36(1):74-81. CrossRef 国 PubMed 圈

14. Rhodes SD, Hergenrather KC. Attitudes and beliefs about hepatitis B vaccination among gay men: the Birmingham Measurement Study. J Homosex 2008;55(1):124-49. CrossRef 圈 PubMed 圈

15. Brownson RC, Baker EA, Leet TL, Gillespie KN. Evidence-based public health. New York (NY): Oxford University Press; 2003.

16. Folta SC, Bell R, Economos C, Landers S, Goldberg JP. Psychosocial factors associated with young elementary school children's intentions to consume legumes: a test of the theory of reasoned action. Am J Health Promot 2006;21(1):13-5. CrossRef 国 PubMed 国

17. Gittelsohn J, Song HJ, Suratkar S, Kumar MB, Henry EG, Sharma S, et al. An urban food store intervention positively affects food-related psychosocial variables and food behaviors. Health Educ Behav 2010;37(3):390402. CrossRef 圈 PubMed 圈

18. Birch LL. Effects of peer models' food choices and eating behaviors on preschoolers' food preferences. Child Dev 1980;51(2):489-96.

19. Bandura A. Social foundations of thought and action: a social cognitive theory. Englewood Cliffs (NJ): PrenticeHall; 1986.

20. Glasgow RE, Vogt TM, Boles SM. Evaluating the public health impact of health promotion interventions: the REAIM framework. Am J Public Health 1999;89(9):1322-7. CrossRef 圈 PubMed 圈

21. Steckler A, Linnan L, editors. Process evaluation for public health interventions and research, 1st edition. San Francisco (CA): Jossey-Bass; 2002.

22. Briss PA, Zaza S, Pappaioanou M, Fielding J, Wright-De Agüero L, Truman BI, et al. Developing an evidencebased guide to community preventive services - methods. The task force on community preventive services. Am J Prev Med 2000;18(1 Suppl):35-43 PubMed 圈

23. Colapinto CK, Malaviarachchi D. Paint your plate: effectiveness of a point-of-purchase display. Can J Diet Pract Res 2009;70(2):66-71. CrossRef 圈 PubMed 圈

24. O'Loughlin J, Ledoux J, Barnett T, Paradis G. La Commande du Coeur (“Shop for Your Heart”): a point-of-choice nutrition education campaign in a low-income urban neighborhood. Am J Health Promot 1996;10(3):175-8. CrossRef 圈 PubMed 圈

25. Crawford SM, Kalina L. The shop smart tour. J Nutr Educ 1993;25(2):10oB.

26. Rosecrans AM, Gittelsohn J, Ho LS, Harris SB, Naqshbandi M, Sharma S. Process evaluation of a multiinstitutional community-based program for diabetes prevention among first nations. Health Educ Res 2008;23 (2):272-86. CrossRef 圈 PubMed 圈

27. Scott JA, Begley AM, Miller MR, Binns CW. Nutrition education in supermarkets: the lifestyle 2000 experience. Aust J Public Health 1991;15(1):49-55. CrossRef 圈 PubMed 圈

28. Gittelsohn J, Dyckman W, Frick KD, Boggs MK, Haberle H, Alfred J, et al. A pilot food store intervention in the republic of the Marshall Islands. Pac Health Dialog 2007;14(2):43-53. PubMed 圈

29. Steenhuis I, van Assema P, van Breukelen G, Glanz K. The effectiveness of nutrition education and labeling in Dutch supermarkets. Am J Health Promot 2004;18(3):221-4. CrossRef 圈 PubMed 圈

30. van Assema P, Steenbakkers M, Stapel H, van Keulen H, Ronda G, Brug J. Evaluation of a Dutch public-private

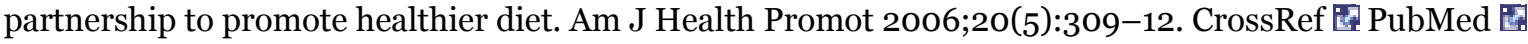

31. van Assema P, Cremers S, Van Dis I. Nutrition education tours in the supermarket: the results of a pilot project in the Netherlands. Food Choice Conference 1996:174-78.

32. Ogawa Y, Tanabe N, Honda A, Azuma T, Seki N, Suzuki T, et al. Point-of-purchase health information encourages customers to purchase vegetables: objective analysis by using a point-of-sales system. Environ Health Prev Med 2011;16(4):239-46. CrossRef 圈 PubMed 圈

33. Mhurchu CN, Blakely T, Funaki-Tahifote M, McKerchar C, Wilton J, Chua S, et al. Inclusion of indigenous and ethnic minority populations in intervention trials: challenges and strategies in a New Zealand supermarket study. J Epidemiol Community Health 2009;63(10):850-5. CrossRef 圈 PubMed 圈

34. Levy AS, Mathews O, Stephenson M, Tenney JE, Schucker RE. The impact of a nutrition information program on food purchases. J Public Policy Mark 1985;4:1-13.

35. Ernst ND, Wu M, Frommer P, Katz E, Matthews O, Moskowitz J, et al. Nutrition education at the point of purchase: the foods for health project evaluated. Prev Med 1986;15(1):60-73. CrossRef 圈 PubMed 圈 
36. Light L, Tenney J, Portnoy B, Kessler L, Rodgers AB, Patterson B, et al. Eat for health: a nutrition and cancer control supermarket intervention. Public Health Rep 1989;104(5):443-50. PubMed 圈

37. Song HJ, Gittelsohn J, Kim M, Suratkar S, Sharma S, Anliker J. A corner store intervention in a low-income urban community is associated with increased availability and sales of some healthy foods. Public Health Nutr 2009;12 (11):2060-7. CrossRef 圈 PubMed 圈

38. Kristal AR, Goldenhar L, Muldoon J, Morton RF. Evaluation of a supermarket intervention to increase consumption of fruits and vegetables. Am J Health Promot 1997;11(6):422-5. CrossRef 因 PubMed 圈

39. Lang JE, Mercer N, Tran D, Mosca L. Use of a supermarket shelf-labeling program to educate a predominately minority community about foods that promote heart health. J Am Diet Assoc 2000;100(7):804-9. CrossRef 圈 PubMed 因

40. Mullis RM, Pirie P. Lean meats make the grade - a collaborative nutrition intervention program. J Am Diet Assoc 1988;88(2):191-5. PubMed 圈

41. Mullis RM, Hunt MK, Foster M, Hachfeld L, Lansing D, Snyder P, et al. The shop smart for your heart grocery program. J Nutr Educ 1987;19(5):225-8. CrossRef 圈

42. Paine-Andrews A, Franciso VT, Fawcett SB, Johnston J, Coen S. Health marketing in the supermarket: using prompting, product sampling, and price reduction to increase customer purchases of lower-fat items. Health Mark Q 1996;14(2):85-99. CrossRef 圈 PubMed 圈

43. Shannon B, Mullis RM, Pirie PL, Pheley AM. Promoting better nutrition in the grocery store using a game format: the shop smart game project. J Nutr Educ 1990;22(4):183-8. CrossRef 圈

44. Jeffery RW, Pirie PL, Rosenthal BS, Gerber WM, Murray DM. Nutrition education in supermarkets: an unsuccessful attempt to influence knowledge and product sales. J Behav Med 1982;5(2):189-200. CrossRef 疄 PubMed 国

45. Gittelsohn J, Vijayadeva V, Davison N, Ramirez V, Cheung LW, Murphy S, et al. A food store intervention trial improves caregiver psychosocial factors and children's dietary intake in Hawaii. Obesity (Silver Spring) 2010;18 (Suppl 1):S84-90. CrossRef 圈 PubMed 圈

46. Curran S, Gittelsohn J, Anliker J, Ethelbah B, Blake K, Sharma S, et al. Process evaluation of a store-based environmental obesity intervention on two American Indian reservations. Health Educ Res 2005;20(6):719-29. CrossRef 国 PubMed 圈

47. Baranowski T, Perry CL, Parcel GS. How individuals, environments, and health behavior interact: social cognitive theory. In: Glanz K, Lewis FM, Rimer BK, editors. Health behavior and health education: theory, research and practice. San Francisco (CA): Jossey-Bass; 1997. p. 153-78.

48. Ho LS, Gittelsohn J, Rimal R, Treuth MS, Sharma S, Rosecrans A, et al. An integrated multi-institutional diabetes prevention program improves knowledge and healthy food acquisition in northwestern Ontario First Nations. Health Educ Behav 2008;35(4):561-73. CrossRef 国 PubMed 国

49. Connell D, Goldberg JP, Folta SC. An intervention to increase fruit and vegetable consumption using audio communications: in-store public service announcements and audio tapes. J Health Commun 2001;6(1):31-43. CrossRef 圈 PubMed 圈

50. Holmes AS, Estabrooks PA, Davis GC, Serrano EL. Effect of a grocery store intervention on sales of nutritious foods to youth and their families. J Acad Nutr Diet 2012;112(6):897-901. CrossRef 因 PubMed 圈

51. Lefebvre RC, Flora JA. Social marketing and public health intervention. Health Educ Q 1988;15(3):299-315. CrossRef 圈 PubMed 圈

52. Dougherty MF, Wittsten AB, Guarino MA. Promoting low-fat foods in the supermarket using various methods, including videocassettes. J Am Diet Assoc 1990;90(8):1106-8. PubMed 圈

53. Olson CM, Bisogni CA, Thonney PF. Evaluation of a supermarket nutrition education program. J Nutr Educ 1982;14(4):141-5. CrossRef 圈

54. Hunt MK, Lefebvre RC, Hixson ML, Banspach SW, Assaf AR, Carleton RA. Pawtucket heart health program pointof-purchase nutrition education program in supermarkets. Am J Public Health 1990;80(6):730-2. CrossRef 圈 PubMed 国

55. Rodgers AB, Kessler LG, Portnoy B, Potosky AL, Patterson B, Tenney J, et al. "Eat for Health": a supermarket intervention for nutrition and cancer risk reduction. Am J Public Health 1994;84(1):72-6. CrossRef 因 PubMed 因

56. Probart CK. In-store consumer nutrition education utilizing student educators. J Nutr Educ 1993;25(1):25-8. CrossRef 圈

57. Reger B, Wootan MG, Booth-Butterfield S, Smith H. 1\% or less: a community-based nutrition campaign. Public Health Rep 1998;113(5):410-9. PubMed 圈 
58. Soriano E, Dozier DM. Selling nutrition and heart-healthy diet behavior at the point-of-purchase. J Appl Nutr 1978;30(1\&2):56-65.

59. Winett RA, Moore JF, Wagner JL, Hite LA, Leahy M, Neubauer TE, et al. Altering shoppers' supermarket purchases to fit nutritional guidelines: an interactive information system. J Appl Behav Anal 1991;24(1):95-105. CrossRef 国 PubMed 圈

6o. Wagner JL, Winett RA, Walbert-Rankin J. Influences of a supermarket intervention on the food choices of parents and their children. J Nutr Educ 1992;24(6):306-11. CrossRef 圈

61. Anderson ES, Winett RA, Wojcik JR, Winett SG, Bowden T. A computerized social cognitive intervention for nutrition behavior: direct and mediated effects on fat, fiber, fruits, and vegetables, self-efficacy, and outcome expectations among food shoppers. Ann Behav Med 2001;23(2):88-100. CrossRef 圈 PubMed 园

62. Levy AS, Schucker RE, Tenney JE, Mathews O. Consumer demand for detailed nutrition information: a case study. J Nutr Educ 1988;20(4):161-6. CrossRef 圈

63. Schucker RE, Levy AS, Tenney JE, Mathews O. Nutrition shelf-labeling and consumer purchase behavior. J Nutr Educ 1992;24(2):75-81. CrossRef 国

64. O'Loughlin J, Renaud L, Richard L, Gomez LS, Paradis G. Correlates of the sustainability of community-based heart health promotion interventions. Prev Med 1998;27(5 Pt 1):702-12. CrossRef 圈 PubMed 圈

65. O'Loughlin J, Paradis G, Kishchuk N, Gray-Donald K, Renaud L, Fines P, et al. Coeur en sante St-Henri - a heart health promotion programme in Montreal, Canada: design and methods for evaluation. J Epidemiol Community Health 1995;49(5):495-502. CrossRef 圈 PubMed 圈

66. Paradis G, O'Loughlin J, Elliott M, Masson P, Renaud L, Sacks-Silver G, et al. Coeur en sante St-Henri - a heart health promotion programme in a low income, low education neighbourhood in Montreal, Canada: theoretical model and early field experience. J Epidemiol Community Health 1995;49(5):503-12. CrossRef 国 PubMed 国

67. Ernst N, Frommer P, Moskowitz J. Foods for health: report of the pilot program (publication no. 83-2036). National Institutes of Health; 1983.

68. Odenkirchen JC, Portnoy B, Blair J, Rodgers AB, Light L, Tenney J. In-store monitoring of a supermarket nutrition intervention. Fam Community Health 1992;14(4):1-9.

69. Patterson BH, Kessler LG, Wax Y, Bernstein A, Light L, Midthune DN, et al. Evaluation of a supermarket intervention. Eval Rev 1992;16(5):464-90. CrossRef 娄

70. Wootan MG, Reger-Nash B, Booth-Butterfield S, Cooper L. The cost-effectiveness of $1 \%$ or less media campaigns promoting low-fat milk consumption. Prev Chronic Dis 2005;2(4):A05. PubMed 圈

71. Reger B, Wootan MG, Booth-Butterfield S. A comparison of different approaches to promote community-wide dietary change. Am J Prev Med 2000;18(4):271-5. CrossRef 圈 PubMed 圈

72. Booth-Butterfield S, Reger B. The message changes belief and the rest is theory: the " $1 \%$ or less" milk campaign and reasoned action. Prev Med 2004;39(3):581-8. CrossRef 圈 PubMed 圈

73. Foerster SB, Gregson J, Beall DL, Hudes M, Magnuson H, Livingston S, et al. The California Children's 5 A Day Power Play! campaign: evaluation of a large-scale social marketing initiative. Fam Community Health 1998;21 (1):46-64. CrossRef 圈

74. Foerster SB, Kizer KW, Disogra LK, Bal DG, Krieg BF, Bunch KL. California’s “5 A Day - for Better Health!” campaign: an innovative population-based effort to effect large-scale dietary change. Am J Prev Med 1995;11 (2):124-31. PubMed 圈

75. van Assema P, Brug J, Glanz K, Dolders M, Mudde A. Nationwide implementation of guided supermarket tours in the Netherlands: a dissemination study. Health Educ Res 1998;13(4):557-66. CrossRef 圈 PubMed 国

76. Gittelsohn J, Dyckman W, Tan ML, Boggs MK, Frick KD, Alfred J, et al. Development and implementation of a food store-based intervention to improve diet in the Republic of the Marshall Islands. Health Promot Pract 2006;7(4):396-405. CrossRef 国 PubMed 圈

77. Gittelsohn J, Anliker JA, Sharma S, Vastine AE, Caballero B, Ethelbah B. Psychosocial determinants of food purchasing and preparation in American Indian households. J Nutr Educ Behav 2006;38(3):163-8. CrossRef 圈 PubMed 圈

78. Song HJ, Gittelsohn J, Kim M, Suratkar S, Sharma S, Anliker J. Korean American storeowners' perceived barriers and motivators for implementing a corner store-based program. Health Promot Pract 2011;12(3):472-82. CrossRef 国 PubMed 圈

79. Gittelsohn J, Suratkar S, Song HJ, Sacher S, Rajan R, Rasooly IR, et al. Process evaluation of Baltimore healthy stores: a pilot health intervention program with supermarkets and corner stores in Baltimore city. Health Promot Pract 2010;11(5):723-32. CrossRef 国 PubMed 固 
80. Sharma S, Cao X, Arcan C, Mattingly M, Jennings S, Song HJ, et al. Assessment of dietary intake in an inner-city African American population and development of a quantitative food frequency questionnaire to highlight foods and nutrients for a nutritional invention. Int J Food Sci Nutr 2009;60(Suppl 5):155-67. CrossRef 圈 PubMed 圈

81. Ni Mhurchu C, Blakely T, Wall J, Rodgers A, Jiang Y, Wilton J. Strategies to promote healthier food purchases: a pilot supermarket intervention study. Public Health Nutr 2007;10(6):608-15. PubMed 圈

82. Seymour JD, Yaroch AL, Serdula M, Blanck HM, Khan LK. Impact of nutrition environmental interventions on point-of-purchase behavior in adults: a review. Prev Med 2004;39(Suppl 2):S108-36. CrossRef 恩 PubMed 圈

83. Achabal DD, McIntyre SH, Bell CH, Tucker NJ. The effect of nutrition P-O-P signs on consumer attitudes and behavior. J Retailing 1987;63:(1)(9-24.

84. Curhan RC. The effects of merchandising and temporary promotional activities on the sales of fresh fruits and vegetables in supermarkets. J Mark Res 1974;11(3):286-94. CrossRef 国

85. Russo JE, Staelin R, Nolan CA, Russell GJ, Metcalf BL. Nutrition information in the supermarket. J Consum Res 1986;13(1):48-70. CrossRef 圈

86. Muller TE. Structural information factors which stimulate the use of nutrition information: a field experiment. J Mark Res 1985;22(2):143-57. CrossRef 国

87. Muller TE. The use of nutritive composition data at the point of purchase. J Nutr Educ 1984;16(3):137-41. CrossRef 国

88. Khan LK, Sobush K, Keener D, Goodman K, Lowry A, Kakietek J, et al. . Recommended community strategies and measurements to prevent obesity in the United States. MMWR Recomm Rep 2009;58(RR-7):1-26. PubMed 圈

89. The Food Trust, New York Supermarket Commission, Food Industry Alliance of New York State, Officials from the City and State of New York. Stimulating supermarket development: a new day for New York, food for every child. Philadelphia (PA): The Food Trust; 2009.

90. Webb K, Hawe P, Noort M. Collaborative intersectoral approaches to nutrition in a community on the urban fringe. Health Educ Behav 2001;28(3):306-19. CrossRef 因 PubMed 因

91. Cohen SJ, Meister JS, deZapien JG. Special action groups for policy change and infrastructure support to foster healthier communities on the Arizona-Mexico border. Public Health Rep 2004;119(1):40-7. PubMed 圈

92. Friedman RR. Access to healthy foods in low-income neighborhoods opportunities for public policy. New Haven (CT): Rudd Center for Food Policy and Obesity; 2008.

93. Giang T, Karpyn A, Laurison HB, Hillier A, Perry RD. Closing the grocery gap in underserved communities: the creation of the Pennsylvania fresh food financing initiative. J Public Health Manag Pract 2008;14(3):272-9. PubMed 圈

94. Robert Wood Johnson Foundation, The Food Trust. Harnessing the power of supermarkets to help reverse childhood obesity. http://www.thefoodtrust.org/pdf/RWJF\%20Food\%20Trust\%20Supermarket\%20Meeting\% 20FINAL\%20electronic\%203.28.11(2).pdf.

95. Moore LV, Diez Roux AV, Nettleton JA, Jacobs DR Jr. Associations of the local food environment with diet quality - a comparison of assessments based on surveys and geographic information systems: the multi-ethnic study of atherosclerosis. Am J Epidemiol 2008;167(8):917-24. PubMed 圈

96. Zenk SN, Schulz AJ, Israel BA, James SA, Bao S, Wilson ML. Neighborhood racial composition, neighborhood poverty, and the spatial accessibility of supermarkets in metropolitan Detroit. Am J Public Health 2005;95(4):660 -7. CrossRef 圈 PubMed 圈

97. Morland K, Diez Roux AV, Wing S. Supermarkets, other food stores, and obesity: the atherosclerosis risk in communities study. Am J Prev Med 2006;30(4):333-9. CrossRef 国 PubMed 圈

98. Morland K, Wing S, Diez Roux A. The contextual effect of the local food environment on residents' diets: the atherosclerosis risk in communities study. Am J Public Health 2002;92(11):1761-7. CrossRef 圈 PubMed 圈

99. Casagrande SS, Franco M, Gittelsohn J, Zonderman AB, Evans MK, Fanelli Kuczmarski M, et al. Healthy food availability and the association with BMI in Baltimore, Maryland. Public Health Nutr 2011;14(6):1001-7.

CrossRef圈 PubMed 圈 
Preventing Chronic Disease | Supermarket and Grocery Store-Based Interventions to P... Page 12 of 20

\section{Tables}

Table 1. Studies Published from 1978 Through 2012 on Supermarket and Grocery Store Interventions $(\mathrm{N}=33$ ) to Promote Healthful Eating, by Strategy Useda

\begin{tabular}{|c|c|}
\hline Strategy/Intervention & Summary Data \\
\hline \multicolumn{2}{|r|}{ Point-of-Purchase } \\
\hline \multicolumn{2}{|c|}{ Supermarket information project (58) } \\
\hline $\begin{array}{l}\text { Setting, location, and } \\
\text { yearb }\end{array}$ & 2 Intervention supermarkets and 1 control supermarket, Fresno, California, 1978 \\
\hline Activities and duration & Index card brochures distributed in stores but designed for home use; 4 months \\
\hline Design & Prospective measurement with comparison group \\
\hline $\begin{array}{l}\text { Main outcomes } \\
\text { measured }\end{array}$ & Awareness and use; knowledge and beliefs; sales data \\
\hline Effectiveness & $\begin{array}{l}\text { No changes in sales of targeted items; tripled anticipated response rate for information } \\
\text { inquiries; store managers reported customer satisfaction with point-of-purchase }\end{array}$ \\
\hline \multicolumn{2}{|c|}{ Supermarket nutrition intervention (52) } \\
\hline $\begin{array}{l}\text { Setting, location, and } \\
\text { yearb }\end{array}$ & 3 Supermarkets in suburbs of northern New Jersey, 1990 \\
\hline Activities and duration & Videocassettes, demonstrations, and printed materialsc; 6 months \\
\hline Design & Prospective measurement with comparison group \\
\hline $\begin{array}{l}\text { Main outcomes } \\
\text { measured }\end{array}$ & Knowledge and beliefs; sales data \\
\hline Effectiveness & No effect on food-purchasing behavior \\
\hline \multicolumn{2}{|c|}{ Nutrition for a Lifetime System (59-61) } \\
\hline $\begin{array}{l}\text { Setting, location, and } \\
\text { yearb }\end{array}$ & $\begin{array}{l}1 \text { Supermarket with control and experimental shoppers, location not available, 1991-2001 } \\
\text { (59) }\end{array}$ \\
\hline Activities and duration & $\begin{array}{l}\text { In-store video programs and printed feedback on intended-purchase function (providing } \\
\text { customers with individualized reduced fat and increased complex carbohydrate } \\
\text { alternatives); } 2 \text { months }\end{array}$ \\
\hline Design & Prospective measurement with comparison group \\
\hline $\begin{array}{l}\text { Main outcomes } \\
\text { measured }\end{array}$ & Sales data; intention; preferences; dietary intake; knowledge and beliefs \\
\hline Effectiveness & $\begin{array}{l}25 \% \text { Greater increase in purchasing of targeted items in intervention compared with control } \\
\text { shoppers; interactive nutrition information system used by more than } 1,400 \text { (nonpaid) } \\
\text { people }\end{array}$ \\
\hline \multicolumn{2}{|l|}{ Paint Your Plate (23) } \\
\hline $\begin{array}{l}\text { Setting, location, and } \\
\text { yearb }\end{array}$ & $\begin{array}{l}11 \text { Stores had interactive display events; } 6 \text { stores had brochures; Greater Sudbury, } \\
\text { Canada, } 2009\end{array}$ \\
\hline Activities and duration & $\begin{array}{l}\text { Interactive display events with public health staff, a display, resources, and food samples } \\
\text { vs brochures; } 1 \text { month }\end{array}$ \\
\hline Design & Prospective measurement with comparison group \\
\hline $\begin{array}{l}\text { Main outcomes } \\
\text { measured }\end{array}$ & Knowledge and beliefs \\
\hline Effectiveness & $\begin{array}{l}\text { Event participants more likely to identify serving size of fruit and vegetables and } \\
\text { recommended number of servings of fruits and vegetables }\end{array}$ \\
\hline
\end{tabular}




\begin{tabular}{|c|c|}
\hline Strategy/Intervention & Summary Data \\
\hline \multicolumn{2}{|c|}{ Educational intervention (44) } \\
\hline $\begin{array}{l}\text { Setting, location, and } \\
\text { yearb }\end{array}$ & 4 Experimental and 4 control supermarkets in Twin Cities, Minnesota, 1982 \\
\hline Activities and duration & Printed materialsc throughout dairy section; 6 months \\
\hline Design & Prospective measurement with comparison group \\
\hline $\begin{array}{l}\text { Main outcomes } \\
\text { measured }\end{array}$ & Sales data; knowledge and beliefs \\
\hline Effectiveness & No clear effect of intervention on nutrition knowledge or sales of targeted products \\
\hline \multicolumn{2}{|c|}{ Point-of-purchase health information (32) } \\
\hline $\begin{array}{l}\text { Setting, location, and } \\
\text { yearb }\end{array}$ & $\begin{array}{l}1 \text { Intervention and } 1 \text { control supermarket, Gosen City, Japan, and Tagami Town, Japan, } \\
2011\end{array}$ \\
\hline Activities and duration & Health-related printed materialsc; 3 months \\
\hline Design & Prospective measurement with comparison group \\
\hline $\begin{array}{l}\text { Main outcomes } \\
\text { measured }\end{array}$ & Sales data \\
\hline Effectiveness & $\begin{array}{l}\text { 18.7 Percentage points greater mean adjusted change in sales of total vegetables in } \\
\text { intervention vs control }\end{array}$ \\
\hline \multicolumn{2}{|r|}{ Point-of-Purchase and Pricing } \\
\hline \multicolumn{2}{|c|}{ Demonstration cancer control project for Iowa farmers (38) } \\
\hline $\begin{array}{l}\text { Setting, location, and } \\
\text { yearb }\end{array}$ & 4 Control and 4 intervention supermarkets, small towns in Iowa, 1997 \\
\hline Activities and duration & Printed materialsc, menus signage; coupons, food demonstrations; 8 months \\
\hline Design & Prospective measurement with comparison group \\
\hline $\begin{array}{l}\text { Main outcomes } \\
\text { measured }\end{array}$ & Awareness and use; fruit and vegetable intake \\
\hline Effectiveness & $\begin{array}{l}18 \% \text { to } 43 \% \text { of shoppers were exposed to intervention activities; no evidence of effect on } \\
\text { consumption of fruits and vegetables }\end{array}$ \\
\hline \multicolumn{2}{|r|}{ Point-of-Purchase and Promotion and Advertising } \\
\hline \multicolumn{2}{|c|}{ Special Diet Alert $(34,62,63)$} \\
\hline $\begin{array}{l}\text { Setting, location, and } \\
\text { yearb }\end{array}$ & $\begin{array}{l}10 \text { Intervention grocery stores in Washington, DC, and } 10 \text { control grocery stores in } \\
\text { Baltimore, Maryland, } 1992\end{array}$ \\
\hline Activities and duration & $\begin{array}{l}\text { Brand-specific shelf markers, take-away information booklets, radio and television spots; } \\
24 \text { months }\end{array}$ \\
\hline Design & Prospective measurement with comparison group \\
\hline $\begin{array}{l}\text { Main outcomes } \\
\text { measured }\end{array}$ & Sales data \\
\hline Effectiveness & $\begin{array}{l}\text { Sales of shelf-marketed products increased; media schedule reach was } 86 \% \text { of target } \\
\text { population }\end{array}$ \\
\hline \multicolumn{2}{|c|}{ M-Fit supermarket shelf-labeling program (39) } \\
\hline $\begin{array}{l}\text { Setting, location, and } \\
\text { yearb }\end{array}$ & 18 Supermarkets, Detroit, Michigan, 2000 \\
\hline Activities and duration & $\begin{array}{l}\text { Color-coded shelf labels, banners, produce and dairy signs, shopping guide; duration } \\
\text { unknown }\end{array}$ \\
\hline Design & Single group, same point in time \\
\hline $\begin{array}{l}\text { Main outcomes } \\
\text { measured }\end{array}$ & Awareness and use \\
\hline
\end{tabular}




\begin{tabular}{|c|c|}
\hline Strategy/Intervention & Summary Data \\
\hline Effectiveness & $\begin{array}{l}\text { Overall intervention awareness was } 28.8 \% \text {; of those aware of the program, } 56 \% \text { used the } \\
\text { program }\end{array}$ \\
\hline \multicolumn{2}{|c|}{ Shop for Your Heart $(24,64-66)$} \\
\hline $\begin{array}{l}\text { Setting, location, and } \\
\text { yearb }\end{array}$ & 3 Grocery stores and 2 supermarkets, Montreal, Canada, 1995-1998 \\
\hline Activities and duration & Printed materialsc, guided tours, taste tests, 1-time cholesterol screening event; 4 months \\
\hline Design & Single group, same point in time \\
\hline $\begin{array}{l}\text { Main outcomes } \\
\text { measured }\end{array}$ & Awareness and use; process measures \\
\hline Effectiveness & Overall intervention awareness $52 \%$; of those aware of the program, $6 \%$ used the program \\
\hline \multicolumn{2}{|l|}{ Foods for Health $(35,67)$} \\
\hline $\begin{array}{l}\text { Setting, location, and } \\
\text { yearb }\end{array}$ & $\begin{array}{l}90 \text { Intervention supermarkets, Washington, DC; comparison supermarkets (number not } \\
\text { reported), Baltimore, MD, 1983-1986 }\end{array}$ \\
\hline Activities and duration & $\begin{array}{l}\text { Shelf and window signs, banners, printed materialsc, newspaper advertising, radio spots; } \\
12 \text { months }\end{array}$ \\
\hline Design & Prospective measurement with comparison group \\
\hline $\begin{array}{l}\text { Main outcomes } \\
\text { measured }\end{array}$ & Awareness and use; knowledge and beliefs; sales data; process measures \\
\hline Effectiveness & Improvements in nutrition knowledge in intervention compared with control group \\
\hline \multicolumn{2}{|c|}{ Food for Health: the Carbohydrate Connection (53) } \\
\hline $\begin{array}{l}\text { Setting, location, and } \\
\text { yearb }\end{array}$ & $\begin{array}{l}3 \text { Intervention supermarkets and } 2 \text { comparison supermarkets, town in New York State, } \\
1982\end{array}$ \\
\hline Activities and duration & $\begin{array}{l}\text { Fact sheet, recipe cards, placard on shelf near target food; newspaper and radio messages; } \\
4 \text { months }\end{array}$ \\
\hline Design & Prospective measurement with comparison group \\
\hline $\begin{array}{l}\text { Main outcomes } \\
\text { measured }\end{array}$ & Awareness and use; knowledge and beliefs; dietary intake; sales data \\
\hline Effectiveness & $\begin{array}{l}\text { Improved nutrition knowledge and food use scores among those aware of the campaign; } \\
\text { increase in purchase of targeted items }\end{array}$ \\
\hline \multicolumn{2}{|c|}{ Eat for Health $(36,55,68,69)$} \\
\hline $\begin{array}{l}\text { Setting, location, and } \\
\text { yearb }\end{array}$ & $\begin{array}{l}\text { >100 Intervention supermarkets, Washington, DC; and } 30 \text { control supermarkets, } \\
\text { Baltimore, Maryland, 1989-1994 }\end{array}$ \\
\hline Activities and duration & $\begin{array}{l}\text { Shelf labels; information guide; monthly bulletin; signs in produce sections; television, } \\
\text { radio, and print advertising; and brief in-store videos; } 24 \text { months }\end{array}$ \\
\hline Design & Prospective measurement with comparison group \\
\hline $\begin{array}{l}\text { Main outcomes } \\
\text { measured }\end{array}$ & Awareness and use; knowledge and beliefs; fat intake; sales data; process measures \\
\hline Effectiveness & $\begin{array}{l}\text { Modest effect on food purchasing behaviors; improved nutrition knowledge, attitudes, and } \\
\text { self-reported food purchasing behaviors; approximately 200,000 people exposed to } \\
\text { campaign }\end{array}$ \\
\hline \multicolumn{2}{|l|}{ Four Heart Program (54) } \\
\hline $\begin{array}{l}\text { Setting, location, and } \\
\text { yearb }\end{array}$ & 3 Supermarkets and 1 grocery store, Pawtucket, Rhode Island, 1990 \\
\hline Activities and duration & $\begin{array}{l}\text { Brand-specific shelf labels, signs, printed materialsc, contests, and blood pressure and } \\
\text { cholesterol screening, counseling, and referral events; } 48 \text { months }\end{array}$ \\
\hline \multirow[t]{2}{*}{ Design } & Multiple measurement, no comparison group \\
\hline & Awareness and use \\
\hline
\end{tabular}




\begin{tabular}{|c|c|}
\hline Strategy/Intervention & Summary Data \\
\hline \multicolumn{2}{|l|}{$\begin{array}{l}\text { Main outcomes } \\
\text { measured }\end{array}$} \\
\hline Effectiveness & $\begin{array}{l}24 \% \text { Correctly identified intervention labels; } 54 \% \text { reported being encouraged to purchase } \\
\text { identified food. Reach: } 1,179 \text { participants and 4,913 population totals; } 636 \text { were } \\
\text { encouraged to purchase labeled products }\end{array}$ \\
\hline \multicolumn{2}{|c|}{ Shop Smart for Your Heart (41) } \\
\hline $\begin{array}{l}\text { Setting, location, and } \\
\text { yearb }\end{array}$ & 17 Grocery stores in 3 Minnesota locations: Mankato, Fargo, and Moorhead, 1987 \\
\hline Activities and duration & $\begin{array}{l}\text { Shelf labels, taste testing, printed materialsc, newspaper advertisement, grocery cart } \\
\text { inserts; } 4 \text { months }\end{array}$ \\
\hline Design & Multiple measurement, no comparison group \\
\hline $\begin{array}{l}\text { Main outcomes } \\
\text { measured }\end{array}$ & Awareness and use \\
\hline Effectiveness & $\begin{array}{l}40 \% \text { Were aware of intervention; } 17 \% \text { to } 41 \% \text { reported that signs influenced their food } \\
\text { choices }\end{array}$ \\
\hline \multicolumn{2}{|c|}{ Lean Meats Make the Grade (40) } \\
\hline $\begin{array}{l}\text { Setting, location, and } \\
\text { yearb }\end{array}$ & 8 Grocery stores in 3 Minnesota locations: Mankato, Fargo, Moorhead, 1988 \\
\hline Activities and duration & Taste testing, printed materialsc, and package labels; 1 month \\
\hline Design & Prospective measurement with comparison group \\
\hline $\begin{array}{l}\text { Main outcomes } \\
\text { measured }\end{array}$ & Awareness and use; knowledge and beliefs; sales data \\
\hline Effectiveness & $\begin{array}{l}\text { Greater awareness in intervention ( } 69 \%) \text { than in comparison ( } 58 \%) \text { communities; } \\
\text { improved nutrition knowledge; increased sales of targeted items }\end{array}$ \\
\hline \multicolumn{2}{|c|}{ Low-fat nutrition education and labeling (29) } \\
\hline $\begin{array}{l}\text { Setting, location, and } \\
\text { yearb }\end{array}$ & 13 Supermarkets including control and 2 intervention groups, the Netherlands, 2004 \\
\hline Activities and duration & Printed materialsc, self-help manual, contest, shelf label; 6 months \\
\hline Design & Prospective measurement with comparison group \\
\hline $\begin{array}{l}\text { Main outcomes } \\
\text { measured }\end{array}$ & Fat intake; knowledge and beliefs; intentions \\
\hline Effectiveness & No significant effects on total fat intake or psychosocial determinants \\
\hline \multicolumn{2}{|c|}{ The Good Book of Nutrition (56) } \\
\hline $\begin{array}{l}\text { Setting, location, and } \\
\text { yearb }\end{array}$ & 6 Chain supermarkets, Central Florida, 1993 \\
\hline Activities and duration & $\begin{array}{l}\text { Taste testing, nutrition information, store advertisements, newspaper advertisements, } \\
\text { cookbook, skirting for information booth, printed banners, posters, package stickers, and } \\
\text { shelf tags; } 1 \text { month }\end{array}$ \\
\hline Design & Single group, same point in time \\
\hline $\begin{array}{l}\text { Main outcomes } \\
\text { measured }\end{array}$ & Awareness and use; knowledge and beliefs \\
\hline Effectiveness & $23 \%$ Of shoppers were aware of campaign; $3 \%$ of shoppers made changes to their diet \\
\hline \multicolumn{2}{|l|}{ Shop Smart Tour (25) } \\
\hline $\begin{array}{l}\text { Setting, location, and } \\
\text { yearb }\end{array}$ & Supermarket chain in 40 communities, British Columbia, 1993 \\
\hline Activities and duration & $\begin{array}{l}\text { Aisle-by-aisle supermarket tour that taught consumers skills in making food choices; follow } \\
\text {-up at } 3 \text { months }\end{array}$ \\
\hline
\end{tabular}




\begin{tabular}{|c|c|}
\hline Strategy/Intervention & Summary Data \\
\hline Design & Before and after, no comparison group \\
\hline $\begin{array}{l}\text { Main outcomes } \\
\text { measured }\end{array}$ & Intentions \\
\hline Effectiveness & $\begin{array}{l}23 \% \text { to } 33 \% \text { of } 48 \text { participants intended to alter dietary behavior in targeted direction; } \\
\text { posttest purchase of low-fat dairy products, whole grain products, and polyunsaturated } \\
\text { spreads was greater than intention to purchase at baseline; posttest purchase of legumes } \\
\text { and tofu was less than intention to purchase at baseline }\end{array}$ \\
\hline \multicolumn{2}{|c|}{$1 \%$ Or Less campaign $(57,70-72)$} \\
\hline $\begin{array}{l}\text { Setting, location, and } \\
\text { yearb }\end{array}$ & $\begin{array}{l}8 \text { Intervention stores in Clarksburg, West Virginia, and Bridgeport, West Virginia, and } 6 \\
\text { comparison stores in Wheeling, West Virginia, 1998-2005 }\end{array}$ \\
\hline Activities and duration & $\begin{array}{l}\text { Focused message was communicated through paid advertising, public relations activities, } \\
\text { and community-based education programs: newspaper, radio, and television } \\
\text { advertisements, press conferences, blinded taste tests at supermarkets; signs in dairy } \\
\text { case; } 2 \text { months }\end{array}$ \\
\hline Design & Prospective measurement with comparison group \\
\hline $\begin{array}{l}\text { Main outcomes } \\
\text { measured }\end{array}$ & Preferences; sales data \\
\hline Effectiveness & Increased sales of targeted items; reach: 231 participants and 257 population totals \\
\hline \multicolumn{2}{|l|}{ Healthy Kids (50) } \\
\hline $\begin{array}{l}\text { Setting, location, and } \\
\text { yearb }\end{array}$ & 1 Intervention store, Roanoke, Virginia, 2012 \\
\hline Activities and duration & Low-to-the-ground kiosk displaying featured food items; 3 months \\
\hline Design & Multiple measurement, no comparison group \\
\hline $\begin{array}{l}\text { Main outcomes } \\
\text { measured }\end{array}$ & Sales data; awareness and use \\
\hline Effectiveness & Overall significant increase in proportion of sales of featured items to total store sales \\
\hline \multicolumn{2}{|l|}{5 A Day $(49,73,74)$} \\
\hline $\begin{array}{l}\text { Setting, location, and } \\
\text { yearb }\end{array}$ & $\begin{array}{l}3 \text { Intervention and } 3 \text { comparison stores, supermarket chain in eastern Massachusetts, } 1995 \\
-2001\end{array}$ \\
\hline Activities and duration & Take-home audiotapes and in-store public service announcements; 1 month \\
\hline Design & Prospective measurement with comparison group \\
\hline $\begin{array}{l}\text { Main outcomes } \\
\text { measured }\end{array}$ & Knowledge and beliefs; fruit and vegetable intake; intentions; process measures \\
\hline Effectiveness & $\begin{array}{l}\text { Increased knowledge scores in intervention group compared with control group; no effect } \\
\text { on fruit and vegetable intake, beliefs, or intentions }\end{array}$ \\
\hline \multicolumn{2}{|r|}{ Point-of-purchase, Pricing, and Promotion and Advertising } \\
\hline \multicolumn{2}{|c|}{ Tasty and Healthy Campaign (30) } \\
\hline $\begin{array}{l}\text { Setting, location, and } \\
\text { yearb }\end{array}$ & 12 Intervention and 6 control butcher shops, Limburg province, the Netherlands, 2006 \\
\hline Activities and duration & $\begin{array}{l}\text { Product labels, price reductions, printed materialsc, mobiles, training employees, television } \\
\text { and radio commercials, newspaper advertisements; } 3 \text { months }\end{array}$ \\
\hline Design & Prospective measurement with comparison group \\
\hline $\begin{array}{l}\text { Main outcomes } \\
\text { measured }\end{array}$ & Dietary intake; awareness and use; intentions \\
\hline Effectiveness & $71 \%$ of customers were aware of campaign; no effects on nutrition behavior or intentions \\
\hline \multicolumn{2}{|l|}{ Kansas LEAN (42) } \\
\hline & 1 Supermarket, Kansas, 1996 \\
\hline
\end{tabular}




\begin{tabular}{|c|c|}
\hline Strategy/Intervention & Summary Data \\
\hline \multicolumn{2}{|l|}{$\begin{array}{l}\text { Setting, location, and } \\
\text { yearb }\end{array}$} \\
\hline Activities and duration & $\begin{array}{l}\text { Prompting by food manufacturer demonstrators consisted of verbal encouragements, taste } \\
\text { samples, and coupons; } 9.5 \text { hours }\end{array}$ \\
\hline Design & Prospective measurement with comparison group \\
\hline $\begin{array}{l}\text { Main outcomes } \\
\text { measured }\end{array}$ & $\begin{array}{l}\text { Trained observers counted the number of targeted food items placed by customers into } \\
\text { their shopping carts. }\end{array}$ \\
\hline Effectiveness & Increased consumer purchases of targeted items \\
\hline \multicolumn{2}{|c|}{ Lifestyle 2000 Flavour Without Fat (27) } \\
\hline $\begin{array}{l}\text { Setting, location, and } \\
\text { yearb }\end{array}$ & 6 Intervention supermarkets, Bunbury, Australia, 1991 \\
\hline Activities and duration & $\begin{array}{l}\text { Large mobiles, vinyl striping on produce bins, shelf talkers, cardboard canopies, and } \\
\text { barbers' poles for dairy cabinets included project logo; low-fat dairy products relocated in } 1 \\
\text { section of the dairy cabinet; coupons, printed materialsc, and option to get Flavour Without } \\
\text { Fat cookbook; low-fat product taste testing; } 4 \text { months }\end{array}$ \\
\hline Design & Single group, same point in time \\
\hline $\begin{array}{l}\text { Main outcomes } \\
\text { measured }\end{array}$ & Awareness and use; process measures \\
\hline Effectiveness & $\begin{array}{l}52 \% \text { Were aware of supermarket promotion; of those aware, } 22 \% \text { reported it had } \\
\text { influenced their food choices; sales of targeted items increased during demonstration } \\
\text { periods }\end{array}$ \\
\hline \multicolumn{2}{|c|}{ Guided supermarket tours $(31,75)$} \\
\hline $\begin{array}{l}\text { Setting, location, and } \\
\text { yearb }\end{array}$ & 9 Supermarkets, The Netherlands, 1996-1998 \\
\hline Activities and duration & $\begin{array}{l}\text { Nutrition education tour given by dietitians (and promoted in mass media); printed } \\
\text { materialsc, games played, taste testing; } 4 \text { months }\end{array}$ \\
\hline Design & Multiple measurement, no comparison group \\
\hline $\begin{array}{l}\text { Main outcomes } \\
\text { measured }\end{array}$ & Knowledge and beliefs; intentions; process measures \\
\hline Effectiveness & $\begin{array}{l}\text { Improved knowledge; } 45 \% \text { of children and } 70 \% \text { of adults intended to buy more low-fat } \\
\text { products }\end{array}$ \\
\hline \multicolumn{2}{|c|}{ Point-of-Purchase, Increased Availability of Healthful Foods, Promotion and Advertising } \\
\hline \multicolumn{2}{|c|}{ Marshall Islands Healthy Stores $(28,76)$} \\
\hline $\begin{array}{l}\text { Setting, location, and } \\
\text { yearb }\end{array}$ & $\begin{array}{l}12 \text { intervention and } 11 \text { control large and small food stores, Majuro Atoll, Republic of the } \\
\text { Marshall Islands; 2006-2007 }\end{array}$ \\
\hline Activities and duration & $\begin{array}{l}\text { Newspaper articles, video, and radio announcements; stocking of key foods; shelf labels, } \\
\text { cooking demonstrations; printed materialsc; } 2.5 \text { months }\end{array}$ \\
\hline Design & Prospective measurement with comparison group \\
\hline $\begin{array}{l}\text { Main outcomes } \\
\text { measured }\end{array}$ & Knowledge and beliefs; awareness and use; process measures \\
\hline Effectiveness & $\begin{array}{l}\text { Exposure associated with increased diabetes knowledge score; sales of select targeted } \\
\text { foods increase; consumer exposure was moderate to high: } 65 \% \text { of respondents had heard } \\
\text { half or more of the } 7 \text { radio spots, } 59 \% \text { had seen half or more of the newspaper ads, and } \\
31 \% \text { had seen video aired on local television; reach: } 120 \text { participants; } 185 \text { population } \\
\text { totals }\end{array}$ \\
\hline \multicolumn{2}{|c|}{ Apache Healthy Stores (AHS) $(46,77)$} \\
\hline $\begin{array}{l}\text { Setting, location, and } \\
\text { yearb }\end{array}$ & $\begin{array}{l}11 \text { Intervention and } 6 \text { comparison stores, White Mountain and San Carlos Apache } \\
\text { reservations, Arizona, 2005-2006 }\end{array}$ \\
\hline Activities and duration & \\
\hline
\end{tabular}




\begin{tabular}{|c|c|}
\hline Strategy/Intervention & Summary Data \\
\hline & $\begin{array}{l}\text { Store managers given "all" and "minimum standard" list of food items to order and } \\
\text { promote; shelf labels and printed materialsc; newspaper cartoons and radio } \\
\text { announcements; cooking demonstrations and taste tests; educational displays; } 12 \text { months }\end{array}$ \\
\hline Design & Prospective measurement with comparison group \\
\hline $\begin{array}{l}\text { Main outcomes } \\
\text { measured }\end{array}$ & Knowledge and beliefs; process measures; intentions \\
\hline Effectiveness & $\begin{array}{l}\text { No effect of intervention reported for cognitive outcomes; } 1,582 \text { contacts made with } \\
\text { customers participating in } 81 \text { cooking demonstrations; average number of customer } \\
\text { contacts/demonstrations was } 21 \text {; reach: } 5 \% \text { of total population }\end{array}$ \\
\hline \multicolumn{2}{|c|}{ Zhiiwaapenewin Akino'maagewin: Teaching to Prevent Diabetes $(26,48)$} \\
\hline $\begin{array}{l}\text { Setting, location, and } \\
\text { yearb }\end{array}$ & $\begin{array}{l}3 \text { Small or convenience stores, } 4 \text { medium-sized stores, and } 1 \text { large supermarket in } 4 \\
\text { communities in northwestern Ontario, Canada, } 2008\end{array}$ \\
\hline Activities and duration & $\begin{array}{l}\text { Stocking and labeling of more healthful foods, printed materialsc, cooking demonstrations, } \\
\text { taste tests; radio, cable television, newsletters, and bulletin boards for educational } \\
\text { materials; } 10 \text { months }\end{array}$ \\
\hline Design & Prospective measurement with comparison group \\
\hline $\begin{array}{l}\text { Main outcomes } \\
\text { measured }\end{array}$ & Process measures; knowledge and beliefs; intentions; awareness and use \\
\hline Effectiveness & $\begin{array}{l}\text { Significant changes in knowledge and frequency of healthful food acquisition among } \\
\text { intervention community respondents }\end{array}$ \\
\hline \multicolumn{2}{|c|}{ Point-of-Purchase, Pricing, Increased Availability of Healthful Foods, and Promotion and Advertising } \\
\hline \multicolumn{2}{|c|}{ Healthy Foods Hawaii (45) } \\
\hline $\begin{array}{l}\text { Setting, location, and } \\
\text { yearb }\end{array}$ & 5 Intervention and 2 comparison stores, Oahu and Big Island, Hawaii, 2010 \\
\hline Activities and duration & $\begin{array}{l}\text { Increased store stocking of nutritious foods, educational displays, shelf labels as } \\
\text { educational tools, cooking demonstrations and taste tests with printed materialsc, and } \\
\text { involvement of local producers and distributors; } 11 \text { months }\end{array}$ \\
\hline Design & Prospective measurement with comparison group \\
\hline $\begin{array}{l}\text { Main outcomes } \\
\text { measured }\end{array}$ & Dietary intake; process measures; knowledge and beliefs; intentions \\
\hline Effectiveness & $\begin{array}{l}\text { Significant effect on caregiver knowledge and attitudes; increased Healthy Eating Index } \\
\text { score; low to moderate exposure to intervention }\end{array}$ \\
\hline \multicolumn{2}{|c|}{ Baltimore Healthy Stores $(17,37,78-80)$} \\
\hline $\begin{array}{l}\text { Setting, location, and } \\
\text { yearb }\end{array}$ & $\begin{array}{l}2 \text { Intervention supermarkets and } 7 \text { Korean corner stores, East Baltimore, Maryland; } 2 \\
\text { control supermarkets and } 6 \text { Korean corner stores, West Baltimore, Maryland, 2009-2011 }\end{array}$ \\
\hline Activities and duration & $\begin{array}{l}\text { Designed to increase availability and sales of healthier food options in local stores; } \\
\text { culturally relevant guidelines, nutrition education training and booklet; printed materialsc, } \\
\text { educational displays, and shelf labels; taste tests, incentives, and giveaways; } 10 \text { months }\end{array}$ \\
\hline Design & Prospective measurement with comparison group \\
\hline $\begin{array}{l}\text { Main outcomes } \\
\text { measured }\end{array}$ & Knowledge and beliefs; process measures; sales data \\
\hline Effectiveness & $\begin{array}{l}\text { No effect on store owner outcome expectations; weekly sales of promoted foods increased } \\
\text { when stocking improved. Reach: 2,942 participants; 55,000 population totals }\end{array}$ \\
\hline \multicolumn{2}{|r|}{ Pricing and Promotion and Advertising } \\
\hline \multicolumn{2}{|c|}{ The Shop Smart Game (43) } \\
\hline $\begin{array}{l}\text { Setting, location, and } \\
\text { yearb }\end{array}$ & 2 Large grocery stores, Bloomington, Minnesota, 1990 \\
\hline Activities and duration & $\begin{array}{l}\text { Aggressively advertised Bingo-style game; flyer with coupons; winning cards entered into } \\
\text { lottery for vouchers good at participating stores; } 7 \text { weeks }\end{array}$ \\
\hline
\end{tabular}




\begin{tabular}{|c|c|}
\hline Strategy/Intervention & Summary Data \\
\hline Design & Multiple measurement, no comparison group \\
\hline $\begin{array}{l}\text { Main outcomes } \\
\text { measured }\end{array}$ & Awareness and use \\
\hline Effectiveness & High awareness of intervention \\
\hline \multicolumn{2}{|c|}{ Supermarket Healthy Options Project (SHOP) $(33,81)$} \\
\hline $\begin{array}{l}\text { Setting, location, and } \\
\text { yearb }\end{array}$ & 8 Supermarkets, Lower North Island, New Zealand, 2007-2009 \\
\hline Activities and duration & $\begin{array}{l}\text { Mailed culturally relevant nutrition education materials to participants' homes; offered price } \\
\text { discounts on eligible healthier food products; participants were required to use, Shop 'N Go, } \\
\text { the electronic handheld scanner system; } 9 \text { months }\end{array}$ \\
\hline Design & Single group, same point in time \\
\hline $\begin{array}{l}\text { Main outcomes } \\
\text { measured }\end{array}$ & Process measures \\
\hline Effectiveness & $\begin{array}{l}\text { No effect of intervention on food purchases reported; mailed recruitment efforts ( } 73 \% \text { of } \\
\text { total recruitment efforts) were more successful than community }(20 \%) \text { or in-store }(7 \%) \\
\text { recruitment efforts }\end{array}$ \\
\hline
\end{tabular}

a Strategies were categorized as point-of-purchase, pricing, promotion and advertising, increased availability of healthful foods, and combinations thereof. Any results reported on reach are included in data on effectiveness. For main outcomes measured, process measures included reach, dose, and fidelity.

b Year study was published; if several articles described the same intervention, the range of years of publication is provided. c Printed materials included at least 2 items, such as posters, recipes, or pamphlets.

Table 2. Summary of Evidence (33 interventions), by Intervention Category

\begin{tabular}{|c|c|c|c|c|c|c|}
\hline Strategy/Intervention & $\begin{array}{l}\text { Availability of } \\
\text { Evidencea }\end{array}$ & $\begin{array}{l}\text { Study Design } \\
\text { Suitabilityb }\end{array}$ & Effectivenessc & Reachd & $\begin{array}{c}\text { Summary } \\
\text { Scoree }(0-27)\end{array}$ & Evidencef \\
\hline \multicolumn{7}{|c|}{ Point-of-purchase $(23,32,44,52,58-61)$} \\
\hline Points & 2.0 & 3.0 & 0.5 & 0 & 7.0 & Insufficient \\
\hline \multicolumn{7}{|c|}{ Point-of-purchase and pricing (38) } \\
\hline Points & 1.0 & 3.0 & 0 & 0 & 3.0 & Insufficient \\
\hline \multicolumn{7}{|c|}{ Point-of-purchase and promotion and advertising $(24,25,29,34-36,39-41,49,50,53-57,62-74)$} \\
\hline Points & 3.0 & 2.3 & 1.5 & $0.3 g$ & 12.2 & Sufficient \\
\hline \multicolumn{7}{|c|}{ Point of purchase, pricing, and promotion and advertising $(27,30,31,42,75)$} \\
\hline Points & 2.0 & 2.3 & 1.8 & 0 & 8.0 & Insufficient \\
\hline \multicolumn{7}{|c|}{$\begin{array}{l}\text { Point-of-purchase, increased availability of healthful foods, and promotion and advertising } \\
(26,28,46,48,76,77)\end{array}$} \\
\hline Points & 2.0 & 3.0 & 1.3 & $1 \mathrm{~h}$ & 10.7 & Sufficient \\
\hline \multicolumn{7}{|c|}{$\begin{array}{l}\text { Point-of-purchase, pricing, increased availability of healthful foods, and promotion and advertising } \\
(17,37,45,78-80)\end{array}$} \\
\hline Points & 2.0 & 3.0 & 1.5 & 0.5 & 10.0 & Sufficient \\
\hline \multicolumn{7}{|c|}{ Pricing and promotion and advertising $(33,43,81)$} \\
\hline Points & 2.0 & 1.5 & 1.0 & 0 & 5.0 & Insufficient \\
\hline \multicolumn{7}{|l|}{ All strategies combined } \\
\hline Points & 2.0 & 2.6 & 1.1 & 0.3 & 8.0 & Insufficient \\
\hline
\end{tabular}




\begin{abstract}
a Scored as 1, 2, or 3 points. Intervention strategy or combination of strategies represented by 10 to 30 studies was assigned 3 points; strategy or combination represented by 2 to 9 studies was assigned 2 points; and strategy or combination represented by 1 intervention was assigned 1 point.

b Scored as 1, 2, or 3 points, according to suitability of study design to determine effectiveness $(15,22)$. Greatest suitability (3 points) refers to studies that have concurrent comparison group and prospective measurement of outcomes. Moderate suitability ( 2 points) refers to all retrospective designs or studies that have multiple pre- or postmeasurements but no concurrent comparison group. Least suitability refers to before-after studies that have no comparison group or studies in which outcomes were measured in a single group at the same point in time (1 point). We did not assign zero points for study design.

c Scored as 0 to 3 points, according to effectiveness of the intervention's main outcome measures (eg, awareness and use). For example, studies reporting a $70 \%$ to $100 \%$ increase pre- to posttest or between comparison and intervention groups in awareness or use of the intervention were assigned 3 points. Studies reporting a $26 \%$ to $69 \%$ increase received 2 points. Studies reporting a $1 \%$ to $25 \%$ received 1 point. A score of 0 was assigned if no difference in outcomes was reported between study groups $(29,38,44,46,52,58,77)$.

d Scored as 0 to 3 points. According to the RE-AIM evaluation framework (20), reach is determined by dividing the number of intervention participants by the number of people in the targeted population. For interventions reaching $70 \%$ to $100 \%$ of the population, 3 points were assigned; for $26 \%$ to $69 \%, 2$ points; for $1 \%$ to $25 \%$, 1 point; and for $0 \%$, 0 points.

e Summary score (range, 0-27 points) calculated by multiplying score for availability of evidence and sum of scores for suitability, effectiveness, and reach.

$\mathrm{f}$ Evidence classified according to summary score: insufficient (0-9 points), sufficient (10-18 points), and strong (19-27 points).

g Only 2 of 15 interventions provided this information.

h Two of 3 interventions provided this information.
\end{abstract}

\title{
Comment on this article at $P C D$ Dialogue
}

Learn more about PCD's commenting policy

The opinions expressed by authors contributing to this journal do not necessarily reflect the opinions of the U.S. Department of Health and Human Services, the Public Health Service, the Centers for Disease Control and Prevention, or the authors' affiliated institutions.

For Questions About This Article Contact pcdeditor@cdc.gov

Page last reviewed: April 30, 2014

Page last updated: April 30, 2014

Content source: National Center for Chronic Disease Prevention and Health Promotion

Centers for Disease Control and Prevention 1600 Clifton Rd. Atlanta, GA 30333, USA 800-CDC-INFO (800-232-4636) TTY: (888) 232-6348 - Contact CDC-INFO 